\title{
RESENSI: BAHASA DAN NALAR BANGSA
}

\section{Fariz al-Nizar \\ Pemuja "Ketidakpastian"}

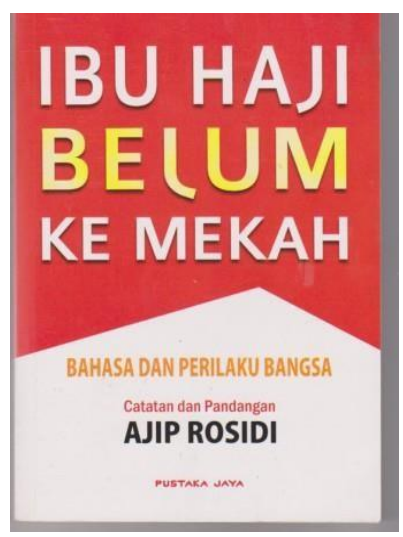

Bahasa sebagaimana dikatakan oleh Anton M. Moeliono (2010) adalah hakikat dari pikiran itu sendiri, bahasa yang sistematis dan baik secara langsung menunjukkan ketertiban pola pikir sang penutur, namun sebaliknya bahasa yang tak sistematis adalah dalil kuat akan keruwetan pikiran sang penutur.

Bahkan mendiang Ayatrohaedi (2009) berpendapat bahwa bahasa merupakan pilar penting dalam membangun sebuah kebudayaan, kebudayaan yang baik secara tidak langsung terbangun dari pondasi berupa kebiasaan serta habit yang baik pula dari pemilik kebudayaan, kebiasaan yang baik sudah barang tentu lahir dari pola pikir yang baik, dan pola pikir yang baik tidak lain bisa tumbuh subur dari bahasa yang baik.

Buku Ibu Haji belum ke Mekkah karya Ajip Rosidi ini mengurai pentingnya bahasa dalam membentuk karakter bernalar sebuah bangsa, kebenaran dalam menggunakan bahasa yang tentu disertai dengan kebenaran menalar akan mendongkrak kualitas kehidupan bangsa tersebut.

$\begin{array}{ll}\text { Data Buku : } & \\ \text { Judul } & \text { : Ibu Haji Belum ke Mekah } \\ \text { Pengarang } & \text { : Ajip Rosidi } \\ \text { Penerbit } & \text { : Pustaka Jaya } \\ \text { Cetakan } & \text { : November } 2012 \\ \text { Tebal } & \text { : 189 hal+cover }\end{array}$

Kebobrokan kita sebagai bangsa dalam menggunakan bahasa tercermin misalnya dalam menggunakan idiomatik (kata?) pulang- pergi, keluar-masuk. Betapapun idiomatik pulang-pergi dan keluar- masuk itu sama sekali tak masuk di akal jika kita nalar dengan jelih. Untuk idiomatik pulang-pergi, bagaimana mungkin kita pulang duluan sebelum pergi itu dilakukan? Begitupun juga dengan keluar- masuk, kapankah pekerjaan keluar itu bisa kita lalui jika kita tak masuk duluan? 
Masalah nalar bahasa yang mempunyai implikasi langsung dengan perilaku bangsa di bahas secara panjang lebar di dalam bagian pertama buku ini, misalnya tentang penggunaan kata "halo apa kabar" dianggap mempunyai dampak atas kebiasaan bangsa kita ngrumpi, suka mengobrol setiap ada kesempatan, bagitu juga bangsa kita tersohor bangsa yang ramah tapi banyak cakap (hal. 44).

Bangdingkan dengan orang Inggris misalnya, mereka menggunakan salam dengan bahasa "how do you do?". Ingat yang ditekankan di sini adalah kata "do". Bisa dibuktikan hari ini bahwa produktivitas orang Inggris jauh melampaui produktivitas kita di bidang apapun. Apalagi di bidang pembangunan manusianya.

Bagian kedua buku ini membahas tentang masalah pelajaran bahasa, dalam bagian ini Ajip lebih banyak mengungkapkan kegelisahannya tentang mutu tulisan para siswa sekolah. Bahwa para siswa pintar teori bahasa mungkin iya, tapi apakah hal itu secara serta merta membuat siswa mampu menulis? Tentu tidak.

Sebagaimana dikatakan Qaris Tajudin (2012) bahwa melatih siswa sekolah yang mahir teori bahasa tapi tumpul kompetensi dalam menulis agar ia bisa menulis itu setara dengan sulitnya menumpahkan saos yang masih baru dibuka segel tutupnya. Ia penuh tapi sulit untuk dituangkan, perlu kocokan serta tenaga ekstra untuk menumpahkannya. Kekhawatiran lain adalah kegemaran menyingkat, menurut Ajip hal ini perlu mendapat perhatian serius dari badan bahasa untuk dikaji secara lebih mendalam atau paling tidak hal ini menarik bagi para linguis serta pemerhati bahasa untuk mengkaji apa sebabnya, apakah karena bangsa kita tidak suka berbelit-belit ria? (hal 72)

Dibagian ketiga dibahas kesantunan-kesantuan dalam berbahasa, kegetiran sang penulis sangat terasa tatkala membicarakan tentang gaya bahasa kuminggris yang melanda hampir seluruh elemen bangsa kita, mulai pejabat sampai dengan tukang pijat. Bahkan untuk yang satu ini Ajip berpesan bahwa hendaknya kata- kata yag kita ucapkan jangan sampai penuh dengan kata-kata atau ungkapan-ungkapan bahasa Inggris yang tak perlu digunakan hanya untuk bergensi, seakan-akan bahasa Indonesia tak cukup mampu untuk menyampaikan gagasan, pikiran dan perasaannya (hal 85).

Hal senada juga pernah diungkapkan oleh Alif Danya Munsyi (2006) yang menyatakan bahwa gempuran bahasa kuminggris ini sangat cepat melumat bahasa-bahasa kita, bahkan termasuk melumat bahasa daerah yang terkenal kokoh, seorang pedagang kain batik di pasar klewer Solo berkata pada seorang calon pembelinya "menawi mundutipun kathah kula 
paringi discount", amboi dari mana kata discount ini menyusup serta menjadi racun bagi indahnya musikalitas bahasa daerah?

Bagian keempat serta kelima dari buku ini lebih membahas tetang arti istilahistilah yang ada dan sering menjadi masalah dalam

nomeklatur kebahasaan kita, seperti anomatope, etimologi, ghost writer dan lain sebagainya.

Sebagai kumpulan kolom yang dimuat secara berkesinambungan dalam media massa, buku ini tidak menuntut syarat agar dibaca secara runtut sebagaimana banyak tradisi buku utuh yang mengharuskan pembaca untuk membaca secara runtut agar mampu menangkap maknanya. Buku ini bisa dicomot dari bagian mana saja pembacanya menghendakinya.

Tapi karena sifatnya yang merupakan kolom media massa itu jugalah yang membuat buku ini terkesan jauh dari tradisi ilmiah, yakni setiap berargumentasi menyebutkan sumbernya, mencantumkan rujukan yang jelas sehingga pembaca bisa mengecek kebenaran serta kesahihan argumentasi yang dilontarkan seorang penulisnya.

Namun hal itu tak berarti mengurangi bobot keilmuan buku ini, karena sebagaimana kita ketahui bahwa kelebihan seorang Ajip Rosidi adalah ia bukan ahli bahasa, namun ia adalah pengguna bahasa, bukan sembarang pengguna bahasa. Ia juga intens terlibat dalam sejarah pembentukan dan perkembangan bahasa Indonesia. Ia dengan fasih bisa menuturkan pengalamannya tentang perdebatan- perdebatan yang pernah terjadi sepanjang ia menggeluti kegiatannya dalam pengembangan bahasa Indonesia.

Pada akhirnya, buku yang terdiri dari 50 kolom bahasadalam rubrik "stilistika" harian Pikiran Rakyat Bandung ini sangat layak untuk dijadikan pegangan para pengkaji bahasa, akademisi sekaligus peminat sejarah kebahasaan mengingat serta menimbang begitu gamblangnya penulis menjelaskan alur serta asal-asul dan perdebatan kebahasaan di dalamnya. Wallahu a'lam bis showab. 